\section{Water, mining, and waste: an historical and economic perspective on conflict management in South Africa}

Rebecca A. Adler, Marius Claassen, Linda Godfrey, and Anthony R. Turton

$\mathrm{L}$ imited water resources have been a source of international conflict for centuries, often as part of wider religious, ideological, political, or economic 1 challenges. The first recorded accounts of such disputes can be traced to Sumeria around $3000 \mathrm{BC}$, although water resources continue to underlie disputes. ${ }^{1}$ Due to the continent's geography and climate, as well as its severe poverty, Africa's variable and unreliable resources have contributed to numerous conflicts, predominantly water, agriculture, and livestock. Subsequent conflicts between European settlers over access to mineral resources in South Africa magnified problems within the water sector, typified by the blatant use of government policies during the apartheid era to favor the mining industry at the expense of the population majority. Following the advent of democracy in 1994, South Africa's challenges have been based on upholding citizens' constitutional rights to have equal access to water and other natural resources.

If left unmanaged, the current struggle over constitutional rights - exemplified by the struggle of a portion of the country to attain access to water - represents a real potential for conflict. If a significant portion of the population remains without access to potable water and the mining industry continues to visibly pollute and modify the water table without consequence, the current government risks losing its legitimacy. The effects of this could vary from a loss of foreign direct investment in South African industries to social unrest, or even civil war. Already a significant decline is seen in the number of South Africans who participate in the political process through voting and voicing their opinions through public participation processes; if this pattern continues, even more are likely to become inactive citizens. Additionally, since access to modern water delivery infrastructure is divided among racial lines, ${ }^{2}$ the failure of the government to provide quality water to all could further contribute to the high level of violent crime and continued racial tension within the country. There is, thus, a need to understand the drivers of this conflict at a practical level and to develop and improve on - new, sustainable, and implementable policy solutions.

In accordance with this need, this article focuses on water problems associated with the mining industry. It outlines the history of the industry in the context of waterresource driven conflict. This background is used to focus on two drivers of conflict pertaining to the mining sector at the subnational level: (1) the laissez faire approach by government to regulation of the mining industry following the Anglo Boer war and (2) the negative externalities associated with mining activities, including but not

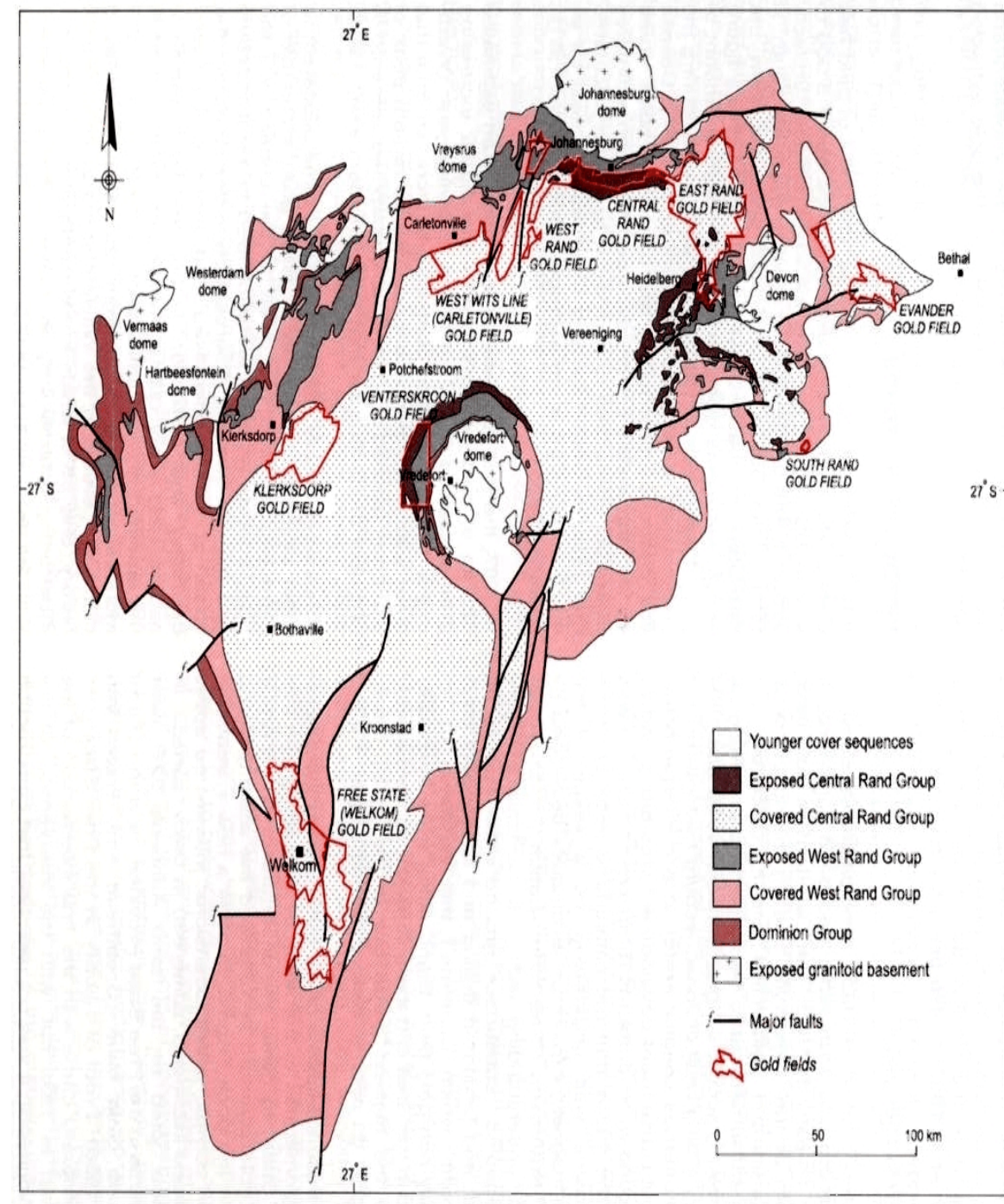

Figure 1: Simplified map of the Witwatersrand goldfields. Located at $\mathrm{S} 27^{\circ}, \mathrm{E} 27^{\circ}$, this is South Africa's largest and most lucrative mining area. The geological groups and sequences of the Witwatersrand goldfield include the Younger cover sequences, the Exposed Central Rand Group, the Covered Central Rand Group, the Exposed West Rand Group and Covered West Rand Group, the Dominion Group, and the Exposed granitoid basement. Major goldfields are denoted in red; major faults in black. Figure modified from Robb and Robb, 1998, p. 350. 
limited to contamination of ground and surface water and the subsequent damage to human and environmental health and ground stability, as well as socioeconomic, political, and financial effects. Both of these drivers are unified under an elementary economic model. The understanding of South Africa's past and the recognition of behavioral patterns described by economic theory together can be used to develop and implement better policy that addresses the conflict associated with mining and the resulting access to potable water.

\section{A brief history of mining in South Africa}

Following the discovery of immense gold resources in South Africa in 1886, the mining industry played a central role in the country's economic, political, and social environment. Because minerals in South Africa are highly diversified, plentiful, and profitable, ${ }^{3}$ government has allowed the industry to be privileged, enabling it to maximize profits. But South Africa recently incorporated objectives of sustainability and social justice into its constitution. ${ }^{4}$ To understand the coevolution of these two goals - profits and justice - in South African history, it is beneficial to look at the mining industry in two phases. The first of these centers on the struggle to profit from the largest gold reserve in the world and is exemplified by the Anglo Boer war. ${ }^{5}$ The second and current phase is characterized by the recognition of the cumulative impact of a century of privileged mining under which the industry maximized profits and externalized costs. The discussion provides a foundation for understanding minerelated water conflict in South Africa today.

Not based on notions of sustainability, the early gold-economy was simply an extractive industry with little consideration given to possibly adverse long-term effects. Supported by decades of water policies that classified water use by the mines separately from water use by other industries, ${ }^{6}$ the mining-based economy developed in the Far West Rand which held the largest gold deposit in the world. Awesome in their value, these deposits lay at great depth that made extraction technically complex and physically dangerous, in part because they were overlain by large dolomitic aquifers. To extract the maximum amount of gold, the industry employed elaborate pumping systems to draw groundwater from the sunken shafts. Unintended consequences included a lowered natural water table and compromised ground stability. It also caused much of the groundwater to be exposed to pyrite and other minerals which had an adverse impact on water quality through acidification and subsequent heavy metal contamination. Although farmers complained about the changes in water quantity and quality as early as 1905, there was little response from the government until 1956 when an Interdepartmental Committee (IDC) was established to investigate the effects of mine dewatering practices. ${ }^{7}$ The final report of an IDC subcommittee, known as the Jordaan Commission Report, was released in 1960. Based on detailed cost-benefit analysis, it recommended the dolomites be dewatered. ${ }^{8}$ Even after taking into account pumping costs, water replacement schemes, and the long-term consequences of dewatering, the value of the additional gold produced over a period of 60 years, the report said, would be at least 3.5 times greater than if the mines were not dewatered.

The government adopted the Commission's recommendations. Sufficient mine closure plans were not developed, and regulatory measures were "amicable agreements" rather than new and enforceable legislation. ${ }^{9}$ Government continued, as it had in the past, to profit from the industry by collecting approximately 57 percent of all mining profits in the form of taxes and levies. ${ }^{10}$ In this sense, entrepreneurial and profit interests of the large mining houses merged with those of the state. This led in essence to the abandonment of regulatory responsibility. Ordinarily, the expectation would be for government to act in behalf of its citizens, regulate the industry, setting standards, and ensuring adherence to those standards. Instead, government allowed its definition of mineral ownership, based on Roman-Dutch Common Law, to justify its passive position toward the industry in support of an unsustainable, yet highly lucrative extractive process. Government failed in its regulatory role, leaving the mining industry to self-regulate. ${ }^{11}$

With the transition to democracy in 1994, the philosophy regarding the ownership of natural resources changed. In the past, those who owned land owned the water and the mineral resources that lay above and below the surface. The adoption of the new Constitution and the Minerals and Petroleum Resources Development Act changed this. ${ }^{12}$ Natural resources became the people's collective property, with government acting as the central custodian. In addition, stakeholders were given the right to access information and to inform the policymaking process. ${ }^{13}$ Although many social justice issues were addressed with this legislation, deficiencies in current legislation remain, as do challenges pertaining to policy enforcement. Additionally, cumulative adverse effects of mining need to be rectified.

Economic theory of unsustainable mining

Mine owners took advantage of weak governmental regulation by externalizing costs. According to elementary microeconomic theory, a firm maximizes profit by producing output so long as its marginal private benefit exceeds its marginal private cost. When a mine can deflect certain short- and long-run production costs - e.g., adverse socio-economic and environmental effects - onto third parties, the mine's private costs are held artificially low and overmuch production results. Called negative externalities, these deflected costs are imposed on stakeholders other than the firm itself; they are not internalized by the firm as it makes production decisions. Achieving efficiency in an economic sense would require that marginal social, rather 


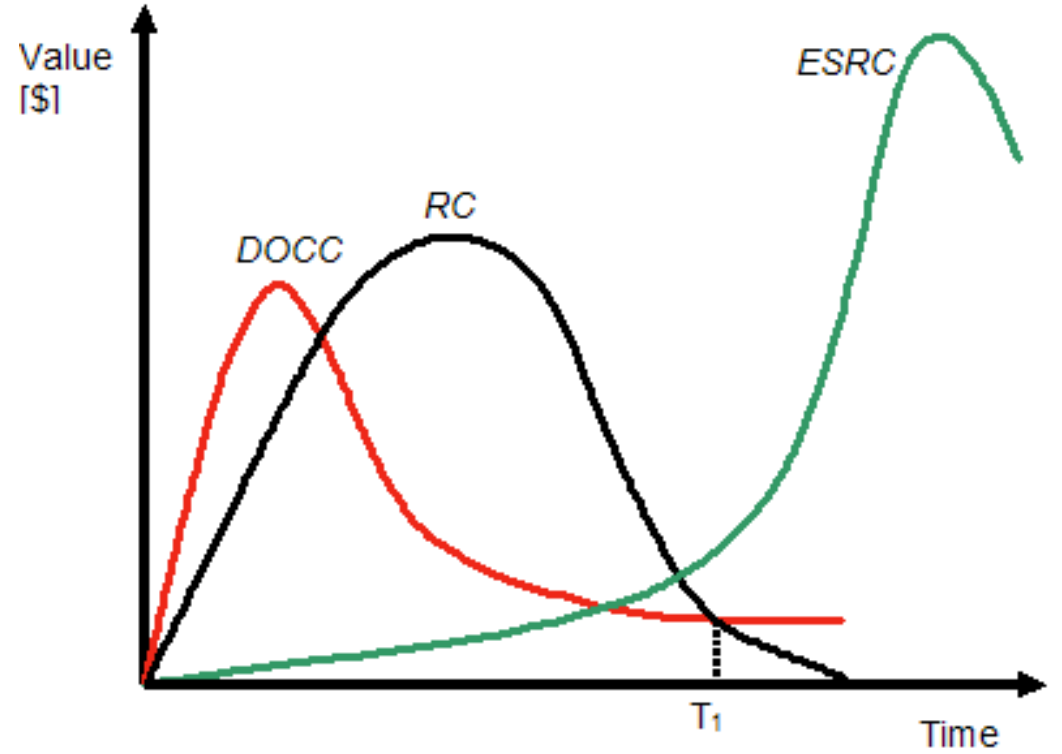

Figure 2: Theoretical representation of the externalization of costs by the goldmining industry in South Africa. The Development and Operational Cost Curve (DOCC) is in red, the Revenue Curve (RC) is in black, and the Environmental and Social Remediation Curve (ESRC) is in green. Note that the sustainability of the industry is not a matter of total profitability at any point in time, but is a function of the total area under each curve. Following mine closure (T1), the ESRC costs continue to accrue, whereas revenue and development costs approach zero within a relatively short time span.

than private, costs per unit of extraction be equated with marginal social benefits. But in the absence of government intervention to compel internalization of negative externalities, the socially optimal (i.e., lower) output level is not obtained. Instead, the social cost is absorbed by the surrounding communities and other stakeholders.

These economic concepts can also be applied to the life-cycle of a mine, i.e., costs and benefits of commissioning, mining, and decommissioning. Importantly, negative externalities associated with mining are often delayed, and accumulate for decades after mineral extraction. ${ }^{14}$ For this reason, the social costs associated with mining are difficult to predict and to regulate. Meanwhile, in the short term, these delayed - and hence less "visible" - costs make the total social cost appear deceptively low.

Figure 2 represents costs and benefits associated with gold mining. The vertical axis expresses value in monetary terms (i.e., US\$ or local monetary equivalent), and the horizontal axis represents time. The Development and Operational Cost Curve (DOCC) refers to the cost of developing and operating a specific mine. This includes costs of prospecting, sinking of mine shafts, pumping of ground water, cooling of shafts, along with developing and employing water treatment facilities and complying with other environmental regulations. The Revenue Curve (RC) represents the revenue generated by the mine. The area under the curves thus equals cumulative development and operational costs and cumulative operational revenues. The difference between the two lines at any one point in time equals profit earned by the mine at that instance. The difference between the total areas under DOCC and $\mathrm{RC}$ reflects lifetime profitability of the mining operation.

The financial success of a mine has historically been represented by the cost of development and operation (DOCC) and the revenues generated (RC). These are balance

sheet items reported to shareholders. Mine closure occurred when revenue streams dropped below the cost of operating the mine (to the right of T1).

The third curve in Figure 2, the Environmental and Social Remediation Curve (ESRC), represents the costs associated with rehabilitation of mining operations after decommissioning, including the cost to human and environmental health and the social legacy of people employed, supported, and attracted to the mine and its surrounding areas. Importantly, this factors in impacts on affected populations that live off-mine, something that is never brought onto any balance sheet. This curve is slow to gain amplitude because the environmental impacts of mining are cumulative and typically require several decades to take effect. By the time environmental and socioeconomic consequences become noticeable, the mines have typically closed or become insolvent and thus cannot be compelled anymore to contribute to remediation, either financially or through other actions.

The outcome of these effects can be described in terms of a governance Trialogue Model $^{15}$ (Figure 3). It shows how regulation (or lack thereof) can result in conflict among industry, government, and environment (which includes society-at-large). ${ }^{16}$ The historical relationship between government and the mining sector, and the 
emphasis on the promotion of economic development in South Africa, has resulted in a public perception of government being unable or unwilling to properly regulate and manage mine-water and mine-waste. As a consequence of this sentiment, and of cumulative adverse mining effects over the past several decades, society - bearing the majority of the environmental and social costs - has become a third partner in the Trialogue. Pressure is therefore exerted by society on government and the mining sector to remedy environmental and social impacts associated with mining practices.

Crossroads of past and future: remaining challenges facing government and industry

Understanding the historical interaction between mining industry and government, and seeing how the economic model demonstrates the effect of this relation, permits one to acknowledge weaknesses within existing frameworks and recognize the crucial need for new, strong, and coherent legislation. Because the issues facing the mining industry are inherently complex, regulation must be geared toward management of a variety of factors. In this section, challenges associated with mineral residue and mine waste management, along with mine water management are discussed. Attention is paid to existing vulnerabilities within the current legislative framework, and how an understanding of the historical legacy and of basic economic theory can be used to address present and future conflict.

\section{Lack of interdepartmental coordination}

Although water, mine, and waste legislation has been redrafted following the collapse of apartheid, many of the changes have not been successfully implemented. The mines exploited these weaknesses to continue to externalize some of their costs. Among the main reasons for the non-implementation of legislation are insufficient specificity and interdepartmental disagreements about which policies are primary. For example, mine water management is handled through four primary and several secondary pieces of legislation and by three different government departments. Even more fragmented, mining waste ${ }^{17}$ is addressed through at least two primary and eleven secondary pieces of legislation and by three primary and six secondary government departments. There is no unifying policy outlining how mining waste and mine water issues are to be addressed. As a consequence, the factors driving the management of mineral residue and mine waste are heavily fragmented between economic development and environmental protection (Figure 4).

Although many believe that potential conflicts among national, provincial, and municipal powers with regard to water, mining, and waste has been addressed by the delegation of powers among agencies in the Constitution, ${ }^{18}$ there remain ambiguities. For example, the national government is empowered to regulate issues pertaining to the environment, pollution control, and soil conservation. But although various

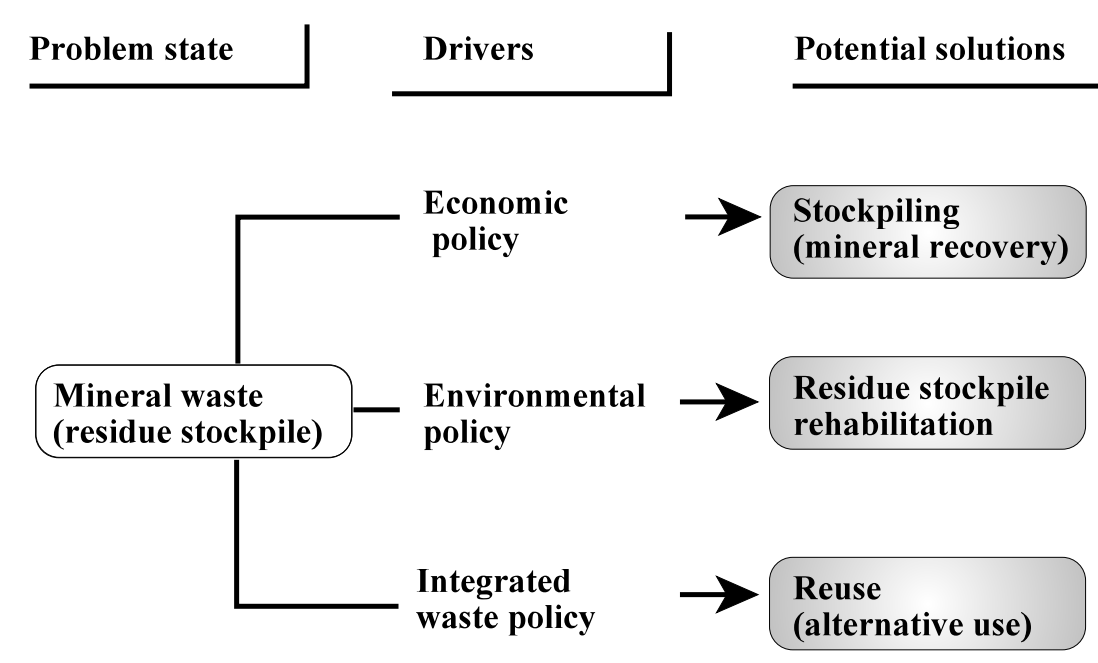

Figure 4: Drivers of mineral waste management in South Africa. The decision of how to handle mineral waste is driven by (1) economic policy, (2) environmental policy, and (3) integrated waste policy. Each of these favors different potential solutions, e.g., stockpiling, rehabilitation, and reuse. Note that these solutions can be used in combination.

government departments are charged with administering policies in these areas, regional or provincial representatives of the national agencies are empowered to enforce these policies at the local level. ${ }^{19}$ In terms of mining waste, the provincial government is responsible for establishing a detailed inventory of all potentially polluting sites within their jurisdiction and for developing hazardous waste management plans. ${ }^{20}$ The plans should include waste minimization, recycling, and reuse initiatives for both industrial and mining waste. Hazardous waste reduction at source and responsible disposal, including alternative treatment options, should feature in the initiatives. Municipal governments are empowered to legislate on matters listed in Part B of Schedules 4 and 5 of the Constitution, ${ }^{21}$ which include control and management of waste as well as water and sanitation services. Both provinces and municipalities are empowered to administer any laws that they have passed. But in all cases, national government may override provincial or municipal authorities in instances in which it becomes necessary to maintain national security, economic unity, essential national standards, the provision of minimum standards for the rendering of services, or to prevent unreasonable provincial action, which will be prejudiced or to the interest of another province, or the whole country.

By creating concurrent legislative competencies among different spheres of 
government, the possibility for conflicting legislation is created. For example, water quality standards will be imposed at a national level; however, local governments are responsible for legislation concerning the treatment of water and sanitation services. There is potential for legislative conflict in this situation, as well as a likelihood that instead of promoting integration, it will create division. This is a result of the seemingly ad hoc appearances in Sections 4 and 5 of the Constitution of certain pollution control functions without the whole picture having been adequately considered. The Constitution, however, requires that the responsibility for waste management functions is to be devolved to the lowest possible level of government, in accordance with the right to self-determination. ${ }^{22}$

The interdepartmental conflicts are magnified by the shortage of governmental officials, and the high turnover of government officials tasked to enforce policies pertaining to water and waste. The inability to integrate across government departments through policy leads to the mismanagement or abandonment of the mineabandoned residue stockpiles and "dumps" that scatter the South African landscape. Where abandoned mine dumps remain on privately owned property, property owners have neither the mandate nor finances to remine, reuse, or rehabilitate them, making the underlying land a personal liability and difficult to sell. The result is a loss in private land value due to on-site abandoned mine dumps over which the landowner has no legal right but bears environmental and social liability, and the loss in private land value due to environmental degradation from neighboring abandoned mine dumps. Additionally, these stockpiles and dumps compromise local water quality through the mobilization of chemicals from run-off and airborne particulates that accumulate in water sources or sediment.

In terms of international legislation, the division of powers among national, provincial, and municipal bodies is one of the primary factors that separates mature mining from immature mining policies. ${ }^{23}$ Until existing legislation can be enforced in a logical, organized fashion at all levels, and until the various government departments can learn how to coordinate with one another to maximize overall efficiency, conflict arising from the lack of government enforcement of current policies and their cumulative impacts will persist in South Africa.

Proactive versus reactive governance

Existing frameworks place government in a reactive position. This is evident in the pricing structures and enforcement mechanisms used to discourage pollution using the polluter-pays principle (PPP), in the legal framework which outlines requirements for environmental impact assessments (EIAs), and in the disagreement about key terms that must be understood for policy enforcement. Until government can be proactive, historical trends will continue, potentially eroding public confidence further.

The PPP, as outlined by the White Paper on Environmental Management Policy for South Africa and the National Water Act of 1998, stipulates that those who are responsible for producing, permitting, or causing pollution, should be held liable for the clean-up costs and the costs of legal enforcement associated with that pollution. ${ }^{24}$ One problem with this approach is that it not only requires government to establish what body is doing the polluting, and by how much (it is technically difficult to assess pollution released through non-point sources), but also allows the polluter to hire private consultants to assess damage and establish an appropriate remediation plan. While government expects these consultants to report accurately, their incentive is to produce data that is to the best advantage of the polluter.

Most countries require EIAs prior to the initiation of new mining projects. Indeed, this is now considered international best practice. Yet because they are reactive, shortsighted, and largely incomplete or inaccurate, EIAs can be considered as a lip-service to legislation. This is inherent in the way in which they are conducted. Since an EIA, in South Africa as elsewhere, is created following the feasibility study of a mining project, it is often based on incomplete geotechnical information and engineering designs. Furthermore, EIAs are conducted at the beginning of the project. Yet mining projects and the surrounding areas are not static; they change over time. ${ }^{25}$ For these reasons, the information on which legislation is based may lead to an underestimate of the eventual environmental and socio-economic impacts, allowing costs to be externalized, particularly if the industry is self-regulating in a fledgling democracy with a history of social injustice. At present, policies pertaining to mining waste and mine water management pay little attention to the short-term and long-term impacts of mining activities on human health. Currently, the only health-related concerns that are addressed by the legislation pertain to occupational health and safety of mine workers themselves, ignoring off-mine populations. Health impact assessments conducted prior to the establishment of a new mining facility tend to be environmentally focused as part of the EIA but are often superficial and reactive in nature. ${ }^{26}$ No high-confidence epidemiological studies of off-mining populations have yet been done, and so there are no baseline data to which to compare changes in a population's health over time.

There are also problems with definitions in the legislation. For example, unlike the cases of the European Union, the United Kingdom, and the United States, South Africa does not currently legally define mineral residue as waste. ${ }^{27}$ As a result, residue stockpiles are often left unprotected, causing environmental pollution and hazards to off-mine populations. Defining mineral residue as waste will provide a legal mandate to internalize environmental and social externalities, bringing them onto firms' balance sheets, and ensuring sound budgeting and consideration for post-closure rehabilitation or reuse of mineral waste. In addition, water quality standards are also not explicit and are, therefore, in many instances difficult to enforce.

Conflict as motivation for reform

Recently, there has been a great deal of interest in the issue of mine-contaminated 
water, with numerous high profile news stories dedicated to the subject. Generally, there is growing concern that environmental and human health risks are not being adequately addressed. ${ }^{28}$ In recent news, Robinson Lake, a mine-waste site with water nearing a $\mathrm{pH}$ of 2.0 containing elevated levels of heavy metal contamination, ${ }^{29}$ has been sold by a large mining company to a developer with plans to create an up-market complex, including a shopping center, private residences, and a hotel. ${ }^{30}$ Acidic mine water is also decanting upsteam into the Cradle of Humankind, a World Heritage Site that contains some of the oldest known hominid fossils ${ }^{31}$ and to which many tourists and research scientists are attracted. A close correlation between this decant point and elevated levels of ${ }^{238} \mathrm{U}$ has been observed. ${ }^{32}$ Additionally, highly visible scandals involving organized crime syndicates, high ranking government officials, and mining representatives have been reported on. The most notable of these is now known as the Brett Kebble affair in which Kebble, a reportedly corrupt mine magnate, is alleged to have embezzled millions of dollars from the mines and was murdered by criminals with alleged ties to the police commissioner and head of Interpol. ${ }^{33}$

Several publicly available scientific studies reveal alarming levels of heavy-metals and radionuclides downstream of mining activities. ${ }^{34}$ Significantly, all have been commissioned post-apartheid as science has been democratized into the service of society. In the absence of national standards on uranium levels in water (something not deemed relevant under apartheid), a series of risk assessments - using Tier 1 Risk Assessment Methodology $y^{35}$ - were conducted to begin to understand the magnitude of the problem in areas that drain the major mining regions. ${ }^{36}$ These studies identified a number of elements that are found in concentrations well in excess of international norms. Risk assessment of ${ }^{238} \mathrm{U}$ using the guideline value of $20 \mu \mathrm{g} / \mathrm{l}$ for the chemical toxicity of uranium in drinking water proposed by Wade and Winde shows a wide distribution of alarmingly high values. ${ }^{37}$ In this regard, all of the rivers that drain into the Vaal basin (the source of drinking water for Johannesburg) are contaminated, thus making it an issue of great national significance and a potential driver of conflict if left unmanaged.

These alarming occurrences should not be used to fuel anger, hatred, or resentment toward the mining industry or the current government; rather, they should be used as motivation for the public to participate in the political process and to encourage government to work toward more unified, proactive policy and legislative frameworks. Corruption in the United States business sector, represented by the Enron scandal a few years ago, led to a major reform in U.S. policy. Similarly, the current situation in South Africa could serve to motivate positive results as an informed public engages with their elected political leadership.

\section{Conclusion}

Since negative externalities associated with mining were not internalized under apartheid, the mining industry failed to adequately prepare for closure and to dispose of mine water and waste in a manner that is consistent with current international best practice. Following the transition to democracy, government faces conflict caused by the legacy of weak regulation that has exaggerated problems associated with limited natural resources. In particular, cumulative harm to off-mine populations resulting from modified water tables, contaminated ground water sources, acidic mine drainage, and ground instability must be addressed before they lead to even more devastating socioeconomic, political, and environmental damage. New policies have been drafted to address these issues, but in most cases the regulation of mining-related activities is fragmented throughout multiple pieces of legislation, to be enforced by various agencies at the national, provincial, and municipal levels. Additionally, the legislation is reactive, rather than proactive, in addressing externalities. Given these facts, it is necessary that government officials and policymakers recognize that the key to solving South Africa's mining problems cannot originate from legislation alone Rather, solutions will come from a synthetic understanding of South Africa's complex history, basic microeconomic theory, and the development of enforceable policies. To this end it is hoped that economics-based research can help to inform that process by understanding drivers of conflict in such a way that appropriate policy interventions can be designed and applied.

Notes

Rebecca A. Adler, the corresponding author (adler.rebecca@gmail.com), is a 20062007 T.J. Watson fellow; Marius Claassen is Manager for Water Resources in the Natural Resources and the Environment Unit at the Council for Scientific and Industrial Research; Linda Godfrey is a Research Group Leader in Pollution and W aste in the Natural Resources and the Environment Unit at the Council for Scientific and Industrial Research; Anthony R. Turton is the Strategic Research Leader: Water Resource Competency Area, in the Natural Resources and the Environment Unit at the Council for Scientific and Industrial Research.

\section{Gleick (1998).}

2. According to recent statistics provided by the Department of Water Affairs and Forestry (DW AF), approximately 80 percent of white South Africans have access to water delivery infrastructure, as compared to approximately 20 percent of black South Africans.

3. Viljoen and Reimold (1999).

4. DJCD (1996)

5. Barber (1999); Farwell (1999); Nasson (1999); Porch (2000); Turton, et al. (2006). 
The Economics of Peace and Security Journal, ISSN 1749-852X

(C) www.epsjournal.org.uk - Vol. 2, No. 2 (2007)

6. Voss $(1968 ; 1978)$.

7. Adler, et al. (2007).

8. Jordaan, et al. (1960).

9. Jordaan (1963).

10. Jordaan, et al. (1960).

11. For more insight into how the relation between the mining industry and the government evolved, see Adler, et al. (2007).

\section{DJCD (1996); DME (2002).}

\section{DJCD (2000).}

14. Externalities associated with mining include modification of the water table, acidic mine drainage, and decreased water quality and result in subsequent damage to human and environmental health and cumulative socioeconomic and political damage.

15. The model (see Turton, et al., 2007) is adapted to include mining, thereby providing a perspective on mineral-waste governance through the perspective of the mining sector.

16. See Hattingh, et al. (2005); Turton, et al. (2007); and Godfrey (2007). The environment is defined here in its broadest sense as comprising three systems: social, economic, and ecological (see Mebratu, 1998).

17. As of 1997, South Africa was estimated to produce 533 million tons of waste per annum, 468 million tons ( 87.7 percent) of which was classified as mineral waste, making the mining industry the country's single greatest polluter. The gold sector alone generates an estimated 47 percent of all mineral waste (DW AF, 2001).

18. For instance, Dale (1997).

19. DJCD (1996, Sections 4 and 5).

20. DEAT (1999), RSA (2000).

21. DJCD (1996).
Adler, Claassen, Godfrey, and Turton, Water, mining, waste: South Africa p. 39

22. DJCD (1996, Section 235).

23. IIED (2002).

24. DW AF (1998, Sec. 19-20); Taviv, et al. (1999).

25. Sassoon (2000).

26. Adler and Rascher (2007).

27. EU: BRGM (2001); U.K.: BGS (2006); U.S.: U.S. EPA (2006).

28. Templehoff (2007a).

29. Coetzee, et al. (2005).

30. Templehoff (2007b)

31. Fourie (2005).

32. Coetzee, et al. (2005).

33. McGreal (2006).

34. Kempster (1996); IWQS (1999); Wade, et al. (2002); Coetzee, et al. (2002); Coetzee, et al. (2005); Coetzee, et al. (2006).

35. Claassen, et al. (2001). A Tier 1 assessment for a given substance takes a national standard, or in the absence of a national standard an established international norm, and compares this to the measured value at a given sampling site. This is expressed as a quotient that divides the measured value by the standard. A quotient value of $<1$ means that the environmental value complies with the standard, whereas values above 1 signify violation of the standard. Values near 1 typically should be subjected to a Tier 2 assessment to reduce uncertainties.

36. Wade, et al. (2002); Coetzee, et al. (2005); Wade and Winde (2005).

37. Wade and Winde (2005). Uranium is used as an indicator of risk since it is directly associated with Witwatersrand mining activities in the study area (Kempster, et al., 1996; IW QS, 1999) and has been identified as the contaminant of most concern in the Wonderfontein Spruit catchment (Wade and Winde, 2005). 


\section{References}

Adler, R., N. Funke, K. Findlater, and A. Turton. 2007. "An Assessment of the Relationship Between the Government, the Mining Industry and the Role of Science in the Far West Rand of South Africa." Contract Report for the Council for Geosciences. Submitted by the W ater Resource Governance Systems Research Group, CSIR: Pretoria. Report No. CSIR/NRE/WR/ER/2007/0019/C.

Adler, R. and J. Rascher. 2007. "A Strategy for the Management of Acid Mine Drainage From Gold Mines in Gauteng." Contract Report for Thutuka (Pty) Ltd. Submitted by the Water Resource Governance Systems Research Group, CSIR: Pretoria. Report No. CSIR/NRE/PW/ER/2007/0053/C.

Barber, J. 1999. South Africa in the Twentieth Century. Oxford: Blackwell Publishers.

[BGS] British Geological Survey. 2006. "Legislation \& policy: mine waste." See http://www.bgs.ac.uk/mineralsuk/planning/legislation/minewaste.html [accessed 28 August 2006].

BRGM. 2001. "Management of mining, quarrying and ore-processing waste in the European Union." Study made for DG Environment, European Commission. Coordination by P. Charbonnier, December 2001. BRGM/RP-50319-FR.

Claassen, M., W.F. Strydom, K. Murray, and S. Jooste. 2001. "Ecological Risk Assessment Guidelines." WRC Report number TT 151/01.pp 21 + xii

Coetzee, H., P. Wade, G. Ntsume, and W. Jordaan. 2002. "Radioactivity study on sediments in a dam in the W onderfontein Spruit catchment." DW AF-Report 2002, Pretoria.

Coetzee, H., J. Venter, and G. Ntsume. 2005. "Contamination of Wetlands by Witwatersrand Gold Mines - Processes and the Economic Potential of Gold in Wetlands." Council for Geosciences Report No. 2005-0106. Pretoria: Council for Geosciences.

Coetzee, H., F. W inde, and P.W. W ade. 2006. “An Assessment of Sources, Pathways, Mechanisms and Risks of Current and Potential Future Pollution of Water and Sediments in Gold-Mining Areas of the Wonderfonteinspruit Catchment." WRC Report No. 1214/1/06. Pretoria: Water Research Commission.

Dale, M. 1997. "South Africa: Development of a New Mineral Policy." Resource Policy, Vol. 23, No. 1/2, pp. 15-25.

[DEAT] Department of Environmental Affairs and Tourism. 1999. "National Waste Management Strategy." Version D. Pretoria: Department of Environmental Affairs and Tourism.

[DJCD] Department of Justice and Constitutional Development. 1996. Constitution of the Republic of South Africa: Act No. 108 of 1996. http://www.info.gov.za/documents/constitution/index.htm

[DJCD] Department of Justice and Constitutional Development. 2000. "Promotion of Access to Information Act, Act 2 of 2000." http//www. info.gov.za

[DME] Department of Minerals and Energy. 2002. "Minerals and Petroleum
Resources Development Act, No.28 of 2002." Pretoria: Department of Minerals and Energy.

[DW AF] Department of Water Affairs and Forestry. 1998. "National Water Act No. 36 of 1998." Pretoria: Department of Water Affairs and Forestry.

[DW AF] Department of Water Affairs and Forestry. 2001. "Waste Generation in South Africa." Water Quality Management Series. Pretoria.

Farwell, B. 1999. The Great Boer War. London: Wordsworth Editions

Fourie, M. 2005. "A Rising Acid Tide." The Mail and Guardian Online (12 April 2005).http://www.mg.co.za/articlePage.aspx?articleid=214990\&area=/earthyear/ earth_features

Gleick, P. 1998. "Conflict and Cooperation Over Fresh Water," pp. 105-137 in The World's Water 1998-1999: The Bennial Report on Fresh Water Resources. Covelo, CA: Island Press.

Godfrey, L. 2007. "Ecosystem governance and the trialogue debate: An overview of the trialogue relationship and the engagement along interfaces," in A.R. Turton, H.J. Hattingh, G.A. Maree, D.J. Roux, M. Claassen, and W.F. Strydom, eds. Governance as a Trialogue: Government-Society-Science in Transition. Berlin Springer-Verlag.

Hattingh, J., J. Leaner, G. Maree, W. Strydom, A. Turton, E. van Wyk, M. Claassen, and M. Moolman. 2005. "Towards innovative ways to ensure successful implementation of government tools." Report No. ENV-P-I 2004-083. Pretoria, CSIR.

[IIED] International Institute for Environment and Development. 2002. "Research on Mine Closure Policy, in Mining, Minerals and Sustainable Development." Report commissioned by the International Institute for Environment and Development.

[IWQS] Institute for Water Quality Studies. 1999. "Report on the radioactivity monitoring programme in the Mooi River (Wonderfonteinspruit) catchment." Report, N/C200/00/RPQ/2399.

Jordaan, J.M. 1963. "Minutes of Discussions Between the Honorable P.M.K. Le Roux, Minister of Water Affairs and the Hounrable D.r N. Diedricks Minister of Economic Affairs of the One Hand and Representatives of The Gold Mining Industry of the Other." 18 February, 1963.

Jordaan, J.M., J.F. Enslin, J.P. Kriel, A.R. Havemann, L.E. Kent, and W.H. Cable. 1960. "Finale Verslag van die Tussendepartmentele Komitee insake Dolomitiese Mynwater: Verre Wes-Rand, Gerig aan sy Edele die Minister van Waterwese deur die Direkteur van Waterwese." (In Afrikaans. Translated as, Final Report of the Interdepartmental Committee on Dolomitic Mine-water: Far West-Rand, Directed at His Excellency the Minister of W ater Affairs by the Director of Water Affairs). Pretoria: Department of Water Affairs.

Kempster, P.L., H.R. van Vliet, U. Looser, I. Parker, M.J. Silberbauer, and P. Du Toit. 1996. "Overview of radioactivity in water sources: uranium, radium and thorium.” Final report, IWQS-No: N/0000/00/RPQ/0196, Pretoria. 
McGreal, C. 2006. "South Africa's Police Chief, His Friend the Murder Suspect, and the Crime Syndicate: Commissioner, Who also Heads Interpol, is Under Suspicion of Corruption." The Mail and Guardian Online.

http://www.guardian.co.uk/southafrica/story/0,,1957870,00.html_continue.

27 May 2006 [accessed 28 February 2007].

Mebratu, D. 1998. "Sustainability and Sustainable Development: Historical and Conceptual Review." Environ Impact Assess Rev, Vol. 18, pp. 493-520.

Nasson, B. 1999. The South African War 1899 - 1902. London: Arnold.

Porch, D. 2000. Wars of Empire. London: Cassell \& Co.

Robb, L. and V. Robb. 1998. "Gold in the Witwatersrand basin," in Wilson and Anhaeusser, eds. The Mineral Resources of South Africa. Handbook. Pretoria: Council for Geosciences (CGS).

[RSA] Republic of South Africa. 2000. "White paper on integrated pollution and waste management for South Africa. A policy on pollution prevention, waste minimisation, impact management and remediation." Government Gazette Vol. 417, No. 20978, 17 March 2000. General Notice 227 of 2000.

Sassoon, M. 2000. "Socioeconomic Consequences of Mine Closure," in A. Warhurst and L. Noronha, eds. Environmental Policy in Mining: Corporate Strategy and Planning for Closure. London: Lewis Publishers.

Taviv, et al. 1999. "A Philosophy and Metholdolgy for the Implementation of the Polluter Pays Principle.” WRC Report No. 793/1/99. Pretoria: Water Research Commission.

Templehoff, E. 2007a. “Mynmonopolie se gru-moeras.” Die Beeld (2 February 2007). Tempelhoff, E. 2007b. "Besoedelde Meer Verkoop." Die Beeld (30 January 2007).

Turton A.R., C. Schultz, H. Buckle, M. Kgomongoe, T. Malungani, and M. Drackner. 2006. "Gold, Scorched Earth and Water: The Hydropolitics of Johannesburg." Water Resources Development, Vol. 22, No. 2, pp. 313-335.

Turton, A.R., H.J. Hattingh, G. Maree, D.J. Roux, M. Claassen, and W.F. Strydom, eds. 2007. Governance as a Trialogue: Government - Society - Science in Transition. Berlin: Springer Verlag.

[US EPA] United States Environmental Protection Agency. 2006. "Non-hazarduos waste." http://www.epa.gov/epaoswer/osw/non-haz.htm [accessed 28 August 2006].

Viljoen, M. and W. Reimold. 1999. An Introduction to South Africa's Geological and Mining Heritage. Randburg: The Geological Society of South Africa and Mintek.

Voss, W. 1968. Elements of South African Water Law. Johannesburg: Juta and Co.

Voss, W. 1978. Principals of South African Water Law. Johannesburg: Juta and Co.

Wade, P.W., S. Woodbourne, W.M. Morris, P. Vos, and N.V. Jarvis. 2002. "Tier 1 risk assessment of radionuclides in selected sediments of the Mooi River." WRCProject No K5/1095.

Wade, P.W. and F. W inde. 2005. "Risk assessment," in Coetzee, H. (compiler). "An assessment of current and future water-pollution risk with application to the
Mooirivierloop (Wonderfonteinspruit).” WRC Report No. K5/1214,pp. 138-189. 